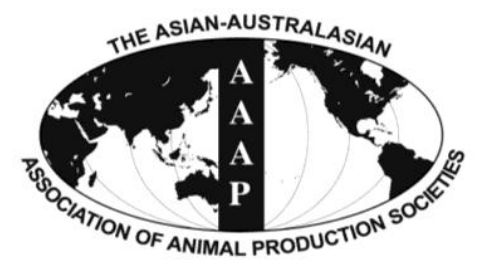

Asian-Aust. J. Anim. Sci.

Vol. 25, No. 9 : 1338 - 1350

September 2012

www.ajas.info

http://dx.doi.org/10.5713/ajas.2012.12282

\title{
Nutrition-induced Changes of Growth from Birth to First Calving and Its Impact on Mammary Development and First-lactation Milk Yield in Dairy Heifers: A Review
}

\author{
J. D. Lohakare ${ }^{1,2, *}$, K.-H. Südekum ${ }^{2}$ and A. K. Pattanaik ${ }^{3}$ \\ ${ }^{1}$ College of Animal Life Sciences, Kangwon National University, KNU Ave 1, Chuncheon 200-701, Korea
}

\begin{abstract}
This review focuses on the nutritional effects from birth until age at first calving on growth, mammary developmental changes, and first-lactation milk yield in heifer calves. The advancement in the genetic potential and the nutritional requirements of the animals has hastened the growth rate. Genetic selection for high milk yield has suggested higher growth capacity and hence increasing nutritional inputs are required. Rapid rearing by feeding high energy or high concentrate diets not only reduces the age of sexual maturity but also lowers the time period of attaining the age of first calving. However, high energy diets may cause undesirable fat deposition thereby affecting future milk yield potential. Discrepancies exist whether overfed or overweight heifers at puberty can influence the mammary development and future milk yield potential and performance. The data on post-pubertal nutritional management suggested that body weight at calving and post-pubertal growth rate is important in first lactation milk yield. There is a continuous research need for strategic feeding that accelerates growth of dairy heifers without reduction in subsequent production. Nutritional management from birth, across puberty and during pregnancy is critical for mammary growth and for producing a successful cow. This review will mostly highlight studies carried out on dairy breeds and possible available opportunities to manipulate nutritional status from birth until age at first calving. (Key Words: Cattle, Heifer, Growth, Mammary Development, Milk Yield)
\end{abstract}

\section{INTRODUCTION}

The ultimate goal of dairy farms is to produce the best cows from replacement heifers. But, replacement heifer management and feeding is expensive and requires extensive labour. It costs approximately $20 \%$ of the farm expenses (Heinrichs, 1993). Reducing the age of onset of puberty, early breeding, and thereby reducing age at first calving (AFC) is the obvious option to minimize expenses on these heifers. In order to achieve this, high energy, high protein, and thus, high concentrate diets are being fed to accelerate growth rates of calves and heifers. Various reports have shown that when accelerated diets are fed before puberty then breeding age and AFC but also firstlactation milk yield (MY) decrease (Gardner et al., 1977;

\footnotetext{
* Corresponding Author: J. D. Lohakare. Tel: +82-33-250-8633, Fax: +82-33-251-7719, E-mail: jayant@kangwon.ac.kr

${ }^{2}$ Institute of Animal Science, University of Bonn, Endenicher Allee 15, 53115 Bonn, Germany.

3 Centre of Advanced Studies in Animal Nutrition, Indian Veterinary Research Institute, Izatnagar, Bareilly 243122, India. Submitted May 22, 2012; Accepted Jun. 24, 2012; Revised Jul. 2, 2012
}

Peri et al., 1993; Hoffman et al., 1996; Sejrsen and Purup, 1997; Radcliff et al., 2000).

Increased pre-pubertal average daily gain (ADG) has been demonstrated to retard mammary development (Sejrsen et al., 1982; Meyer et al., 2006a), sometimes referred to as fatty udder syndrome, thereby affecting future first-lactation MY potential of the animal (Gardner et al., 1977; Lammers et al., 1999; Radcliff et al., 2000). The major critics to rearing heifers at an accelerated growth rate are compromised mammary development and decreased potential of subsequent MY. However, for MY, data is not consistent and suggests that accelerated pre-pubertal gain has less effect on MY in first lactation when AFC is greater than 24 months (Hoffman, 1997; Le Cozler et al., 2008). Also, accelerated post-pubertal growth resulted in earlier calving at similar pre-partum body weight (BW), but heifers fed accelerated diets were smaller in stature and had reduced performance during first lactation (Hoffman et al., 1996). Effects of BW during post-pubertal stage on MY potential and optimum body size of replacement heifers have been extensively reviewed by Hoffman (1997). However, proper assessment and evaluation of the feeding 
and management programmes of replacement heifers is required from birth to AFC by milk producers and proper recommendations are needed.

To maximize lactation performance and reduce rearing costs, average AFC in Holsteins in western countries was recommended to be $\leq 24$ months with 540 to $650 \mathrm{~kg}$ of BW before first calving in high concentrate intensive feeding systems (Hoffman, 1997) and 475 to $550 \mathrm{~kg}$ appears acceptable in pasture-based systems (Holmes et al., 2002; Macdonald et al., 2005). A growth rate of approximately $800 \mathrm{~g}$ /day from 150 to $320 \mathrm{~kg} \mathrm{BW}$ was required for maximum first lactation milk and protein yields in eight studies when calving BW was included in the model (Zanton and Heinrichs, 2005). However, pre-pubertal BW gains, when evaluated on a continuum from 0.5 to $1.1 \mathrm{~kg} / \mathrm{d}$ did not significantly affect MY during the first lactation (Van Amburgh et al., 1998). Only few authors have reported on effects of feeding level after puberty. High energy intake during the post-pubertal period did not negatively influence mammary development (Sejrsen et al., 1982) and might even have enhanced development (Harrison et al., 1983), although enhanced growth rate during the post-pubertal period has demonstrated equivocal changes in MY (Lacasse et al., 1993; Macdonald et al., 2005).

Nutritional effects from weaning until puberty and from post-puberty until AFC and its effects on production performance in future life are inconsistent and equivocal. Variation in responses between experiments suggests that feeding regimes that support high growth rates without negative effect on MY can be developed. This review highlights the nutritional impact during this period on growth, mammary gland development and on milk production potential of the animal.

\section{Mammary gland growth and effects of nutrition}

Mammary growth is a major determinant of MY capacity and longevity of lactation. Mammary gland development starts right from foetal stage and the basic structures are formed in foetal life and outer shape of the glands is fully developed at birth, but epithelial cells are rudimentary (Sinha and Tucker, 1969; Valentine et al., 1987). At this age the mammary ducts and fat pads grow rapidly, but no alveoli are formed (Purup et al., 1993). The mammary gland of heifers develops at the same rate as the rest of the body from birth to about 3 months of age and from 10 to 12 months of age to about 3 months of gestation. Between these two isometric phases of growth and from third month of gestation until calving the mammary gland grows at a faster rate than the rest of the body (Swanson and Poffenbarger, 1979; Valentine et al., 1987). The most rapid pre-pubertal mammary growth relative to body growth occurs from 3 to 9 months of age at BW between 90 and $230 \mathrm{~kg}$ and is the critical period during which the mammary growth of a Holstein heifer can be influenced by nutrition (Tucker, 1987; Johnsson, 1988).

The primary hypothesis to explain reduced MY when replacement heifer growth is accelerated is that the development of mammary secretory tissue is reduced because of the high energy demand to accelerate growth (Hoffman and Funk, 1992). It is clear that mammary parenchymal development is retarded by the shorter period to puberty in rapidly reared heifers (Capuco et al., 1995; Meyer et al., 2006a). The ability of the mammary gland to produce milk depends on number of epithelial cells which is influenced by their rate of proliferation and apoptosis (Knight, 2000; Capuco et al., 2003) and the secretory activity of the myoepithelial cells which is affected by their differentiation (Akers et al., 2006). The angiogenesis or vascular system development (Djonov et al., 2001) required for nutrient supply and removal of metabolic waste products has received no attention in normal mammary development of females (Akers, 2002) but was recently highlighted for goats (Safayi et al., 2010). Also, the metabolic status in the first lactating mammary gland is different because the nutrients are diverted between lactation and continued growth (Wathes et al., 2007).

\section{Nutritional effects from birth to weaning}

Studies on the magnitude of body growth rates during the period between birth and approximately 4 months of age that encourage maximal mammary development and future milk production potential are scarce (Brown et al., 2005a; 2005b). Heifer calves that achieve greater weaning BW, increased growth rates from birth to weaning, or both have been reported to attain puberty at earlier ages (Wiltbank et al., 1966; Arije and Wiltbank, 1971; Buskirk et al., 1995). Table 1 summarizes findings on effects of feeding from birth to weaning on calf performance and milk yield potential.

Feeding whole milk : Young heifer calves consuming whole milk for BW gains of $1.1 \mathrm{~kg} / \mathrm{d}$ tended to produce more milk as cows than did calves fed a restricted amount of whole milk before weaning (Foldager and Krohn, 1994). In support of the above view, Israeli Holstein calves reared by ad libitum milk consumption for the first $50 \mathrm{~d}$ of life as compared with milk replacer (MR) fed calves had higher BW, decreased age of onset of puberty by $23 \mathrm{~d}$, and increased fat-corrected first-lactation MY (Shamay et al., 2005). Whole milk-fed calves had higher BW and ADG at weaning, lower age at first insemination, and lower age at pregnancy and calving than MR fed heifers. Also, the first lactation MY and 4\% fat-corrected MY were higher for whole milk heifers than MR fed animals and pre-pubertal added protein tended to increase MY (Moallem et al., 2010).

Management manipulations : Few studies have attempted to achieve faster growth rates in calves before 
Table 1. Effect of feeding from birth to weaning on calf performance and milk yield potential

\begin{tabular}{ll}
\hline Duration/age & Feeding regime \\
\hline Birth to weaning & $\begin{array}{l}\text { Calves suckling milk twice daily vs } \\
\text { calves fed MR }\end{array}$ \\
Day 1 to d 43 of age & $\begin{array}{l}\text { Ad libitum feeding of milk by artificial } \\
\text { nipples vs milk feeding by bucket at } \\
10 \% \text { of body weight (BW) } \\
\text { Increasing energy and protein intake in } \\
\text { MR to } 8 \text { wks of age }\end{array}$ \\
Until 6 wks of age & $\begin{array}{l}\text { Warm MR }\left(35^{\circ} \mathrm{C}\right) \text { for ad libitum intake } \\
\text { or cold MR for ad libitum intake or } \\
\text { restricted warm MR } 4 \text { L/d in 2 equal } \\
\text { feeds. Fresh concentrate was fed for } \\
\text { ad libitum intake during MR regime } \\
\text { Milk fed vs MR feeding }\end{array}$ \\
\end{tabular}

Birth to $44 \mathrm{~d}$ of age

3 to $56 \mathrm{~d}$ of age

0 to $56 \mathrm{~d}$ of age

4 to 60 days of age
Fed colostrums and whole milk at $20 \%$ of BW for $23 \mathrm{~d}$ and reduced to $10 \%$ of BW for $16 \mathrm{~d}$ and compared with calves fed colostrums and milk at $10 \% \mathrm{BW}$ for $44 \mathrm{~d}$

Conventional MR (20\% CP, 20\% fat) or intensive MR ( $28 \%$ CP, $18 \%$ fat)

Group 1 was fed $0.44 \mathrm{~kg}$ of DM of a $21 \% \mathrm{CP}, 21 \%$ fat MR daily for $42 \mathrm{~d}$, group 2 was fed $0.66 \mathrm{~kg}$ of DM of a $27 \% \mathrm{CP}, 17 \%$ fat MR for $42 \mathrm{~d}$, group 3 was $0.66 \mathrm{~kg}$ of DM of a $27 \% \mathrm{CP}, 17 \%$ fat MR for $28 \mathrm{~d}$ and group 4 was fed $1.09 \mathrm{~kg}$ of DM of a $29 \% \mathrm{CP}, 21 \%$ fat MR for $49 \mathrm{~d}$.

Calves fed on MR or whole milk for $30 \mathrm{~min}$ twice daily. From weaning until $150 \mathrm{~d}$ fed on similar ration, and at $150 \mathrm{~d}$ half of heifers in each subgroup was fed with additional $2 \%$ protein for $320 \mathrm{~d}$ of age

\begin{tabular}{lc}
\multicolumn{1}{c}{ Response } & Authors \\
\hline $\begin{array}{l}\text { Suckling calves produces more milk in their } \\
\text { first lactation }\end{array}$ & Bar-Peled et al. \\
(1997)
\end{tabular}

Feeding by nipples increased weight gain with no detrimental effect in solid feed intake after weaning

Rate of development of mammary parenchyma increased

At weaning calves offered warm MR ad libitum were $30 \%$ heavier than the restricted group with mean growth rates in excess of 1 $\mathrm{kg} / \mathrm{d}$.

BW and all skeletal parameters higher in milk fed calves, reached puberty earlier by $23 \mathrm{~d}$ and increased fat-corrected milk yield (MY) at first lactation

Greater BW gain and structural growth in calves fed at $20 \%$ of BW

Jasper and Weary

Brown et al. (2005a, 2005b)

Bleach et al. (2005)

Shamay et al. (2005)

Khan et al. (2007)

No effect of MR feeding on first-lactation performance, but heifers on intensive high solid MR at high feeding rate calved $27.5 \mathrm{~d}$ earlier

Calves in group 1 had lower ADG and calves in group 4 had highest ADG from 0 to $56 \mathrm{~d}$, the least ADG from 56 to $84 \mathrm{~d}$. No differences in BW at $84 \mathrm{~d}$ in group 2, 3, and 4 calves.

BW at weaning and ADG until weaning were greater $(3.1 \mathrm{~kg}$ and $0.074 \mathrm{~kg} / \mathrm{d})$ in whole milk than MR group. Nursery treatment and protein feeding had no effects on growth rates in pre-pubertal period, but first lactation MY was higher, in whole milk heifers than MR fed heifers weaning. Bleach et al. (2005) carried out an experiment on 75 Holstein-Friesian heifer calves by feeding either warm $\left(35^{\circ} \mathrm{C}\right)$ or cold (ambient temperature) MR for ad libitum intake or a restricted amount of warm $\left(35^{\circ} \mathrm{C}\right) \mathrm{MR}$ (Table 1). Calves offered warm MR ad libitum were approximately $30 \%$ heavier at weaning and this feeding strategy can thus also be used to exploit the early growth potential of dairy heifer calves (Bleach et al., 2005). Greater BW gain, structural growth, and a more metabolically and physically developed rumen were observed in Holstein calves on a step-down method compared with a conventional method (Khan et al., 2007; Table 1). This method could be used as a mean to achieve faster growth rate and early puberty in
Holstein calves. Ad libitum intake of milk by dairy calves through an artificial nipple can allow for increased milk intake and weight gain with no detrimental effects on intake of solid food after weaning when compared with milk feeding by bucket twice daily at $10 \%$ of BW (Jasper and Weary, 2002).

Milk replacer feeding : Feeding calves MR with high nutrient concentrations at a high feeding rate before weaning resulted in increased BW compared with a conventional MR feeding programme yet without effect on first-lactation MY. However, heifers on nutrient-dense MR at high feeding rate pre-weaning calved earlier (RaethKnight et al., 2009). By varying the quantity and 
composition of MR, the growth rate and composition of milk-fed calves can be manipulated (Hill et al., 2010). Previous research comparing production of heifer calves fed either restricted amounts of MR, or allowed to suckle, before weaning, showed that suckled calves had higher BW gains, produced more milk in their first lactation because of higher nutrient intake before weaning (Bar-Peled et al., 1997; Drackley, 2005). Increasing protein and energy intake through MR in Holstein heifer calves from 2 to 8 wks of age can increase the rate of development of mammary parenchyma (Brown et al., 2005a), but whether this increase would translate into higher milk production later in life was not reported. From these studies it becomes evident that early rapid growth until weaning is at least not detrimental for mammary gland development.

Early rapid growth is beneficial if intra-parenchymal fat content of the mammary gland is not increased. Maximising growth rate between 2 and 8 weeks of age might have positive effects on mammary development since increased energy and protein intake at this age nearly doubled the mass of mammary parenchyma (Brown et al., 2005a). Therefore, it seems that feeding more milk or MR to achieve faster gain thereby encouraging lean growth without much intra-mammary fat deposition can be achieved. Overall, it might be possible to influence future productivity by exploiting the growth potential of the heifer during the milk feeding period ( 0 to $8 \mathrm{wks}$ ), before the period of allometric mammary development begins. But there are very few studies that showed a direct effect of preweaning nutrition on future MY and the possibility of confounding the effects of pre-weaning nutritional regime on mammogenesis and MY due to management after weaning are very high.

\section{Nutritional effects from weaning to puberty}

In cattle, puberty onset occurs at approximately the same BW independent of feeding level (Sejrsen et al., 1982; Sejrsen, 1994). In heifers of large dairy breeds, onset of puberty usually occurs at 9 to 11 months of age and at an average BW of 250 to $280 \mathrm{~kg}$ (Sejrsen and Purup, 1997). The attainment of puberty depends more on BW than on age (Macdonald et al., 2005; Macdonald et al., 2007). Also the genetic strain of Holstein-Friesian influences age at puberty mainly through the influence of strain on BW (Macdonald et al., 2007).

Nutritional status between birth and puberty can exert a permanent effect on the ability of adult cows to produce milk (Johnsson, 1988). Increased growth rate due to high feeding level before puberty onset can lead to reduced pubertal mammary growth and reduced MY potential (Sejrsen et al., 2000), if rapid growth occurs with increased body fatness. Very few studies have actually looked at the impact of nutrition on both pre-pubertal mammary gland development and subsequent MY. Generally one or the other aspect has been evaluated with an assumption that both are linked. Table 2 summarizes findings on effects of feeding from weaning to puberty on heifer performance and MY potential. High feed intakes during pre-puberty had negative effects (Sejrsen et al., 2000), no effects (Van Amburgh et al., 1998; Abeni et al., 2000), or positive effects (Choi et al., 1997) on mammary growth and subsequent MY.

Effect of pre-pubertal nutrition on mammary growth : Negative effects of high feeding level in the pre-pubertal period on mammogenesis, especially a reduced amount of parenchyma tissue and a lowered future MY have been observed in several studies in both dairy and beef heifers (Harrison et al., 1983; Capuco et al., 1995; Buskirk et al., 1996, Sejrsen et al., 2000). When Holstein heifers were fed varying amounts of the same diet to achieve two rates of ADG (650 or $950 \mathrm{~g} / \mathrm{d})$, and then slaughtered at BW of 100 , $150,200,250,300$, or $350 \mathrm{~kg}$ to study mammary parenchymal development, showed no effect of rate of gain on mammary parenchyma and had no negative impact on ductal development (Daniels et al., 2009). However, the number of epithelial and luminal structures present in mammary parenchyma increased with increasing BW. In contrast, increasing energy intake of pre-pubertal heifers (age, 11 wks; BW, $107 \mathrm{~kg}$ ) for different durations $(0,3,6$ or 12 wks) decreased the percentage of mammary epithelial cells in terminal ductal area, decreased the mass of fat-free parenchyma per unit of carcass and increased the mass of mammary fat proving negative effects of high-energy diets on mammary parenchymal mass at puberty (Davis Rincker et al., 2008). It appears that feeding high energy diets hastens puberty, but mammary growth is not proportional to body growth and reduces mammary parenchymal tissue.

Silva et al. (2002) suggested that within a dietary treatment, pre-pubertal heifers that grow faster do not have impaired mammary development. Among heifers fed the same high-energy diet for ad libitum intake, those that gained a higher proportion of fat grew slower and had less mammary parenchyma at puberty (Silva et al., 2002). Perhaps, increased body fatness may be a better predictor of impaired mammary development than BW gain. Dietary regimes to achieve heavier BW at first calving, based on moderate rates of pre-pubertal gain followed by high rates of gain during the post-pubertal period, had no detrimental effects on mammary parenchyma development (Carson et al., 2004).

Increasing pre-pubertal BW gains can have a negative impact on mammary parenchyma cell numbers (Meyer et al., 2006a) and first-lactation MY (Lammers et al., 1999; Radcliff et al., 2000). During pre-pubertal allometric phase of growth the mammary parenchymal mass, deoxyribonucleic acid (DNA) content, or both are reduced in heifers reared on an elevated level of nutrient intake 
Table 2. Effect of pre-pubertal feeding on heifer performance, mammary gland and milk yield (MY)

\begin{tabular}{|c|c|c|c|}
\hline Duration/age & Feeding regime & Response & Authors \\
\hline Before puberty & $\begin{array}{l}\text { High feeding level to increase } \\
\text { growth rate }\end{array}$ & $\begin{array}{l}\text { - Decreased pubertal mammary growth } \\
\text { and reduced MY } \\
\text { - No effect } \\
\text { - Positive effects on mammary growth } \\
\text { and subsequent MY } \\
\text { - Decreased mammary parenchymal } \\
\text { mass, DNA content or both } \\
\text { - Decreased mammary parenchyma cell } \\
\text { numbers } \\
\text { - No influence on mammary epithelial } \\
\text { cells proliferation, rate of parenchyma } \\
\text { DNA accretion and the total DNA }\end{array}$ & $\begin{array}{l}\text { - Johnsson (1988); Lammers et } \\
\text { al. (1999); Radcliff et al. } \\
\text { (2000); Sejrsen et al. (2000) } \\
\text { - Van Amburgh et al. (1998), } \\
\text { Daniels et al. (2009) } \\
\text { - Choi et al. (1997) } \\
\text { - Petitclerc et al. (1984); } \\
\text { Capuco et al. (1995); Davis } \\
\text { Rincker et al. (2008) } \\
\text { - Meyer et al. (2006a) } \\
\text { - Meyer et al. (2006b) }\end{array}$ \\
\hline $\begin{array}{l}6 \text { wks of age } \\
\text { until } 300 \mathrm{~kg} \mathrm{BW}\end{array}$ & $\begin{array}{l}3 \text { different dairy breeds with } 3 \\
\text { different energy rations of } 3 \text { different } \\
\text { energy density for ad libitum intake } \\
\text { to support } 3 \text { levels of daily gain }\end{array}$ & $\begin{array}{l}\text { Lowest MY was noted in groups fed at } \\
\text { feeding levels to gain BW above } 350 \text {, } \\
550 \text {, and } 650 \mathrm{~g} / \mathrm{d} \text {, in Jersey, Danish } \\
\text { Reds, and Friesians, respectively }\end{array}$ & Hohenboken et al. (1995) \\
\hline $\begin{array}{l}5 \text { to } 10 \\
\text { months of age }\end{array}$ & $\begin{array}{l}\text { Diet } 1 \text { : CP } 142 \mathrm{~g} / \mathrm{kg} \text { DM with high } \\
\text { rumen undegradable protein (RUP) } \\
(270 \mathrm{~g} \mathrm{RUP} / \mathrm{kg} \mathrm{CP}) \text {, diet } 2 \text { : high CP } \\
(183 \mathrm{~g} \mathrm{CP} / \mathrm{kg} \mathrm{DM}) \text { with low RUP } \\
(133 \mathrm{~g} \mathrm{RUP} / \mathrm{kg} \mathrm{CP}) \text {, diet } 3 \text { : high CP } \\
(182 \mathrm{~g} \mathrm{CP} / \mathrm{kg} \mathrm{DM}) \text { with high RUP } \\
(267 \mathrm{~g} \mathrm{RUP} / \mathrm{kg} \mathrm{CP}) \text {. Energy in diet } \\
\text { was } 11 \mathrm{MJ} \mathrm{ME} / \mathrm{kg} \mathrm{DM} \text {. }\end{array}$ & $\begin{array}{l}\text { Low CP fed group had lowest weight } \\
\text { gain }(918 \mathrm{~g} / \mathrm{d}) \text { than other } 2 \text { groups }(952 \\
\text { and } 990 \mathrm{~g} \text {, respectively), at pre-pubertal } \\
\text { level. Daily first lactation milk, protein } \\
\text { and fat yields were not affected. Diets } \\
\text { with high RUP with } 182 \mathrm{~g} \mathrm{CP} \text { per kg } \\
\text { DM produced } 0.08 \mathrm{~kg} \text { more milk daily } \\
\text { protein. }\end{array}$ & Dobos et al. (2000) \\
\hline $\begin{array}{l}\text { Before puberty } \\
\text { (trial 1) and after } \\
\text { puberty (trial 2) }\end{array}$ & $\begin{array}{l}\text { Fed diets to achieve moderate ( } 0.7 \\
\mathrm{~kg} / \mathrm{d} \mathrm{BW} \text { gain) or accelerated gains } \\
(0.9 \mathrm{~kg} \mathrm{BW} \text { gain). During study, half } \\
\text { of the heifers were mated at first } \\
\text { oestrus after } 370 \mathrm{~kg} \mathrm{BW} \text { and the rest } \\
\text { after } 420 \mathrm{~kg} \text { of BW }\end{array}$ & $\begin{array}{l}\text { BW gains affected the body condition in } \\
\text { post-pubertal stage. No effect on first } \\
\text { lactation performance, accelerated BW } \\
\text { gains after puberty influenced milk fat } \\
\text { content. Early calving negatively } \\
\text { influenced MY }\end{array}$ & Abeni et al. (2000) \\
\hline $\begin{array}{l}200 \text { to } 300 \\
d \text { of age }\end{array}$ & $\begin{array}{l}\text { Bovine somatotropin (bST) and RUP } \\
\text { during early post weaning period } \\
\text { until just prior to puberty }\end{array}$ & $\begin{array}{l}\text { Increase in BW and skeletal growth } \\
\text { without reducing age at puberty in bST } \\
\text { and RUP fed animals }\end{array}$ & Moallem et al. (2004a) \\
\hline
\end{tabular}

(Petitclerc et al., 1984; Capuco et al., 1995). In contrast to others (Sejrsen et al., 1982; Petitclerc et al., 1984; Capuco et al., 1995), Meyer et al. (2006b) found that basal proliferation of pre-pubertal bovine mammary epithelial cells was not negatively influenced by an elevated nutrient intake to achieve $950 \mathrm{~g} / \mathrm{d} \mathrm{BW}$ gain, rather it was increased. The level of nutrient intake, especially of dietary protein, had minimal influence on mammary epithelial cell proliferation, the rate of parenchyma DNA accretion and the total parenchyma DNA (Meyer et al., 2006b). However, mammary fat pads were directly influenced by elevated energy and protein intake, but the same was not true with parenchyma and most of the variation in parenchyma DNA content was accounted for by differences in age and not by the amount of nutrient intake (Meyer et al., 2006a). The authors suggested that this may have confounded many of the previous studies where mammary development was evaluated at a similar BW but at different ages. Therefore, when the impact of nutrition on mammary gland and MY is studied, then both, animals of similar age and at similar BW, should be used to acquire less confounded and more meaningful data.

It has been suggested that rapid rates of growth may be achieved without detrimental effects on subsequent MY, if rapid growth occurs without excessive fattening (Silva et al., 2002). The decrease in MY that is associated with high energy diets fed during the pre-pubertal period has been attributed to reduced growth of mammary parenchyma and a concurrent increase in the deposition of mammary adipose tissue (Swanson, 1960). A high energy intake results in greater deposition of fat in all body tissues (Waldo et al., 1997). However, ad libitum access to a high protein, high 
energy diet (formulated to achieve BW gain of $1.2 \mathrm{~kg} / \mathrm{d}$ ) increased growth rate compared with ad libitum access to a control diet (formulated to achieve BW gain of $0.8 \mathrm{~kg} /$ day) without detrimental effects on mammary development (Radcliff et al., 1997). Thus, extra dietary protein may offset the detrimental effect of high dietary energy on mammary development during the pre-pubertal stage.

Effect of pre-pubertal nutrition on milk yield: Negative effects of high feeding level in the pre-pubertal period, and increasing pre-pubertal BW gains lowered future MY have been observed in several studies in both dairy and beef heifers (Harrison et al., 1983; Capuco et al., 1995; Buskirk et al., 1996, Lammers et al., 1999; Radcliff et al., 2000; Sejrsen et al., 2000). The negative effect of high feeding level on first lactation MY was similar among breeds and it started when the feeding resulted in BW gains above 350, 550 and 650 g/day in Jerseys, Danish Reds and Danish Friesians, respectively (Hohenboken et al., 1995), showing breed differences (Table 2). There are experiments where no negative effects were observed of high feeding levels during the pre-pubertal stage on subsequent MY. This may be due to very small growth rate differences between treatment groups, a small number of animals or treatment periods were outside the critical period (Sejrsen et al., 2000).

Heifers could achieve daily BW gains of approximately $800 \mathrm{~g}$ from 100 to $300 \mathrm{~kg} \mathrm{BW}$ without a negative effect on future MY, if the intakes of total digestible nutrients and crude protein (CP) are in the range of 90 to $110 \%$ of NRC (1989) recommendations (Pirlo et al., 1997). Controlled feeding of a high-concentrate ration during the rearing period especially before puberty to achieve ADG of approximately $825 \mathrm{~g} / \mathrm{d}$ could be utilized as a managerial strategy for dairy heifers to improve fat-corrected milk and fat production in their first lactation (Zanton and Heinrichs, 2007). Zanton and Heinrichs (2007) evaluated growth and first-lactation MY in dairy heifers fed a high-forage or highconcentrate ration for similar levels of $\mathrm{BW}$ gain before puberty and found no difference in puberty attainment and found equal or improved 150-d milk and milk component production. In contrary, reduced first-lactation MY was observed when dairy heifers were offered high-concentrate diets for ad libitum consumption (Radcliff et al., 2000). Similar to Zanton and Heinrichs (2007), others have reported that first-lactation MY did not differ between groups when the high-concentrate diet was restricted to similar BW gains compared with the high-forage control diet (Sejrsen and Foldager, 1992; Carson et al., 2000).

Effect of diet composition during pre-pubertal stage on mammary growth and milk yield: Few studies evaluated the influence of diet composition on mammary growth and MY. Waldo et al. (1998) fed pre-pubertal heifers either lucerne silage or maize silage plus soybean meal for daily BW gains of 725 or $950 \mathrm{~g}$. Feed intake, milk and milk component production, and milk composition during first lactation were not affected by either experimental diet or growth rates (Waldo et al., 1998). In another study, total mammary parenchymal DNA and ribonucleic acid were lower at puberty in heifers fed maize silage-based diets for high rate of BW gain (Capuco et al., 1995); however, mammary growth was not inhibited in heifers fed lucerne silage for higher rates of BW gain, and diets or growth rates had no impact on subsequent milk production. Heifers fed a straw/concentrate-based diet during winter periods had beneficial effects on mammary parenchyma development compared with those on grass silage-based diets, and pasture grazing during summer improved mammary development over maintaining animals indoors on a straw/concentrate-based diet (Carson et al., 2004). Increased deposition of fat in adipose and mammary tissues of heifers fed a maize silage diet between 175 and $325 \mathrm{~kg}$ of BW or with BW gain in excess of $950 \mathrm{~g} / \mathrm{d}$ was also reported (Gaynor et al., 1995).

The effect of accelerated diets during pre-pubertal stage on the early onset of puberty is now widely accepted, however, the effects on mammary development are equivocal and impacts on subsequent milk production are not clearly defined. It seems that heifers with a higher genetic potential for milk also have a higher genetic potential for lean deposition rather than fat accretion. Most of the studies showing negative effects of pre-pubertal accelerated dietary regime on first-lactation MY are confounded with the management practices around puberty, breeding and gestation because of differences regarding age and BW at first calving. Nevertheless, the potential of decreasing age of puberty by accelerated BW gains without subsequently impairing production should be further investigated.

\section{Effect of post-pubertal feeding}

Increased growth rate due to high feeding level after puberty and during gestation had no effect on mammary growth and later MY (Sejrsen et al., 2000). A lack of effect of feeding level after puberty on mammary growth was also shown by Sejrsen et al. (1982) who compared the effect of feeding level from 300 to $440 \mathrm{~kg} \mathrm{BW}$ in unbred US Holstein heifers. Table 3 summarizes findings on effects of post-pubertal feeding on heifer performance and MY potential. Feeding intensity during gestation can influence milk producing ability of primiparous cows by affecting BW at calving and mammary growth and development. The first lactation MY had a positive relationship with BW at first calving (Foldager and Sejrsen, 1991), however, contrarily, high plane of nutrition during gestation had also been shown not to increase MY in such cows (Laccase et al., 1993; Grummer et al., 1995). It seems that the plane of nutrition before gestation and the magnitude and duration of 
Table 3. Effect of post-pubertal feeding on heifer performance, mammary gland and milk yield (MY)

\begin{tabular}{|c|c|c|c|}
\hline Duration/age & Feeding regime & Response & Authors \\
\hline $\begin{array}{l}\text { From } 300 \mathrm{~kg} \text { to } 440 \mathrm{~kg} \mathrm{BW} \\
\text { or } 13 \text { to } 21 \text { months age }\end{array}$ & $\begin{array}{l}\text { Ration with } 60: 40 \\
\text { concentrate to forage ratio } \\
\text { fed in restricted or ad libitum } \\
\text { amounts }\end{array}$ & $\begin{array}{l}\text { No effect on mammary secretory tissue and } \\
\text { mammary parenchyma }\end{array}$ & $\begin{array}{l}\text { Sejrsen et al. } \\
\quad(1982)\end{array}$ \\
\hline $\begin{array}{l}\text { From } 1 \text { yr of age to } \\
3 \text { months of gestation, } \\
\text { and } 3 \text { months of gestation } \\
\text { to } 14 \mathrm{~d} \text { before calving }\end{array}$ & $\begin{array}{l}\text { Fed moderate or accelerated } \\
(\text { ad libitum }) \text { diets }\end{array}$ & $\begin{array}{l}\text { BW gain of } 0.72 \text { and } 0.84 \mathrm{~kg} / \mathrm{d} \text { for heifers fed } \\
\text { moderate or accelerated diets, respectively. No } \\
\text { effect on first lactation MY }\end{array}$ & $\begin{array}{l}\text { Laccase et al. } \\
\qquad(1993)\end{array}$ \\
\hline $\begin{array}{l}10 \text { months of age } \\
\text { until parturition }\end{array}$ & $\begin{array}{l}\text { Heifers fed either control or } \\
\text { diets to achieve faster growth }\end{array}$ & $\begin{array}{l}\text { Accelerated diets had higher daily gain (933 vs } \\
778 \mathrm{~g} / \mathrm{d} \text { ) and calved earlier ( } 21.7 \text { vs } 24.6 \\
\text { months), had higher pre-partum BW and lower } \\
\text { post-partum BW, but reduced performance } \\
\text { during first lactation }\end{array}$ & $\begin{array}{l}\text { Hoffman et al. } \\
\qquad(1996)\end{array}$ \\
\hline \multirow[t]{2}{*}{2 to 6 months of gestation } & $\begin{array}{l}\text { - By increasing feeding } \\
\text { intensity }\end{array}$ & - No effect on MY & $\begin{array}{l}\text { Mäntysaari et al. } \\
\text { (1999) }\end{array}$ \\
\hline & $\begin{array}{l}\text { - reared to gain } 650 \mathrm{~g} / \mathrm{d} \text { prior } \\
\text { to breeding but high feeding } \\
\text { in last trimester }\end{array}$ & - Increased MY & \\
\hline $\begin{array}{l}\text { After puberty and during } \\
\text { gestation }\end{array}$ & $\begin{array}{l}\text { High feeding level to } \\
\text { increase growth rate }\end{array}$ & No effect on mammary growth and MY & $\begin{array}{l}\text { Sejrsen et al. } \\
\text { (2000) }\end{array}$ \\
\hline Post-pubertal phase & High feed allowance & $7 \%$ increase in MY & $\begin{array}{l}\text { Macdonald et al. } \\
\text { (2005) }\end{array}$ \\
\hline $\begin{array}{l}\text { Gravid heifers } \\
(464 \mathrm{~kg} \mathrm{BW} \text { and } 17.5 \text { months } \\
\text { age) }\end{array}$ & $\begin{array}{l}\text { Limit-fed } 90 \text { and } 80 \% \text { of } \\
\text { ad libitum intake more } \\
\text { nutrient-dense diets (12.7 } \\
\text { and } 14.2 \% \mathrm{CP} \text { and } 10.67 \text { and } \\
11.21 \mathrm{MJ} / \mathrm{kg} \text { of } \mathrm{ME} \text {, } \\
\text { respectively) than control } \\
\text { diets for ad libitum intake } \\
(11.3 \% \mathrm{CP} \text { and } 10.29 \mathrm{MJ} / \mathrm{kg} \\
\mathrm{ME}) \text { for } 111 \mathrm{~d} \text {. }\end{array}$ & $\begin{array}{l}\text { Similar growth rates and MY (for } 150 \mathrm{~d} \text { ) in } \\
\text { limit-fed heifers to ad libitum fed heifers, but } \\
\text { feed efficiency increased }\end{array}$ & $\begin{array}{l}\text { Hoffman et al. } \\
\qquad(2007)\end{array}$ \\
\hline
\end{tabular}

high feed intakes are important factors.

High plane of nutrition during post-pubertal period did not increase MY during first lactation but BW gain during complete lactation period decreased and days to first observed estrus increased due to ad libitum feed intake showing negative effect of high plane of nutrition (Laccase et al., 1993) (Table 3). However, contradictory to Laccase et al. (1993), the post-pubertal growth rate was positively correlated with first lactation MY, and MY increased 7\% along with milk fat and protein yield in first lactation heifers on the high feed allowance because of increased animal size (Macdonald et al., 2005). The BW at first calving as well as post-pubertal growth rates are important for first-lactation MY (Macdonald et al., 2005) and it was reported that BW greater than $660 \mathrm{~kg}$ at first calving did not improve lactation performance (Grummer et al., 1995). Heifers fed an accelerated diet from 10 months of age until parturition and bred at 10 or 14 months, respectively, showed higher BW gains and calved earlier than control animals (Hoffman et al., 1996; Table 3). Accelerated growth resulted in higher pre-partum $\mathrm{BW}$ and lower $\mathrm{BW}$ after parturition, but those heifers were smaller and early calving reduced performance during first lactation. Reduced MY during first lactation because of accelerated post-pubertal growth was not always observed. However, it can be postulated that accelerated post-pubertal heifers having lower post-partum BW shift nutrients away from MY to meet growth requirements and compensatory growth is generally seen in such first-lactating cows.

Feeding gravid heifers : Gravid heifers are generally fed low energy, high fibre forages that effectually control energy intake and help minimize over-conditioning at calving which can be detrimental to lactation performance (Hoffman et al., 1996). Gravid Holstein heifers showed improved feed efficiency and no adverse effects on growth or subsequent lactation performance when they were limit fed nutrient-dense diets (Hoffman et al., 2007). Other studies also showed that after conception, BW at calving (Moore et al., 1991) and body condition score at calving (Garnsworthy and Jones, 1987) influence post-partum feed intake and first lactation MY.

The feeding intensity from 2 to 6 months of gestation 
had no effect on milk producing ability of primiparous Ayrshire cows, but a high feeding intensity during the last trimester of pregnancy increased MY (Mäntysaari et al., 1999), possibly due to differences in physiological status (calving BW, body fat reserves) of the heifers at calving (Table 3). Heifers under different post-pubertal feeding regimens with AFC of 20.6 or 23.6 months showed that delayed bred heifers had higher incidence of dystocia because of higher body condition score due to delayed breeding to increase AFC (Hoffman et al., 1996).

There is a scarcity of recent reports investigating the effect of post-pubertal feeding on mammary gland development. It appears that selection for a single trait, namely MY, with little consideration for traits associated with reproduction caused reproductive problems and hence a new strategic direction for genetic selection that also includes reproductive traits is required (Oltenacu and Broom, 2010). Nutritional strategies are also needed that optimize reproductive processes without compromising the partitioning of energy into milk production.

\section{Effect of protein on heifer growth, mammary development and milk yield}

Growing heifers require protein to support maintenance, growth, and pregnancy. The standard protein-to-energy ratio for pre-pubertal dairy heifers is around $9.6 \mathrm{~g}$ metabolizable protein/MJ metabolizable energy (ME), which is equivalent to $13.2 \mathrm{~g} \mathrm{CP} / \mathrm{MJ} \mathrm{ME}$ if rumen-undegradable $\mathrm{CP}$ (RUP) is $36 \%$ of CP (Whitlock et al., 2002). Pre-pubertal BW gain was influenced by dietary $\mathrm{CP}$ concentration showing lower BW gain for low CP than for high CP groups, but dietary RUP concentration did not influence pre-pubertal BW gain (Dobos et al., 2000). The age and BW at calving were not influenced by either pre-pubertal dietary CP or RUP concentrations (Dobos et al., 2000). Heifers fed diets containing low CP between 5 and 10 months of age, had greater area of mammary gland fat tissue and the ratio of fat to secretory tissue area at 16 months of age, compared to high CP fed heifers (Dobos et al., 2000; Table 2). Recent studies showed that for milk fed calves $18.9 \%$ of dietary $\mathrm{CP}$ and for weaned heifers $14.2 \% \mathrm{CP}$ maximized gross nitrogen efficiency (Zanton and Heinrichs, 2008a). Several other studies recommended dietary $\mathrm{CP}$ as $16.0 \%$ for heifers weighing 90 to $220 \mathrm{~kg}, 14.5 \%$ for 220 to $360 \mathrm{~kg}$, and $13.0 \%$ CP for more than $360 \mathrm{~kg} \mathrm{BW}$ (Hoffman, 1997; Pirlo et al., 1997; Waldo et al., 1997; Hoffman et al., 2001; Le Cozler et al., 2008).

Dietary CP at low, standard, or high concentrations (8.8, 9.8, or $10.5 \mathrm{~g} / \mathrm{MJ}$ of $\mathrm{ME}$, respectively) with $\mathrm{ME}$ at 11.9 $\mathrm{MJ} / \mathrm{kg}$ DM did not affect age or weight of heifers at puberty or slaughter at $46 \mathrm{~d}$ after puberty, and carcass composition (Whitlock et al., 2002). Effect of dietary protein levels of 75,
100 and $125 \%$ of Kearl (1982) recommendations on growth of crossbred dairy calves from 3 to 5 months of age for next 105 days was evaluated (Lohakare et al., 2006). The fortnightly BW changes and net BW gain did not differ significantly between treatments in that study. Dietary protein did not cause a major effect on mammary development based on average mammary parenchymal DNA content, provided the diets contain adequate protein for normal body growth, and the new NRC (2001) guidelines for protein relative to energy seem adequate for optimal mammary development (Whitlock et al., 2002).

The potential of increased growth rates to decrease AFC should be fulfilled by increasing $\mathrm{CP}$ intake; therefore the $\mathrm{CP}$ to energy ratio should be higher for rapidly growing heifers than for heifers growing at a standard rate. Few studies reported that insufficient concentrations of dietary $\mathrm{CP}$ in rapidly growing pre-pubertal heifers may impair mammary development and decrease first lactation yield.

Feeding bovine somatotropin along with protein : Some nutritional strategies like feeding bovine somatotropin (bST), which is not allowed to use in the European Union, has shown positive effects on pre-pubertal mammary secretory tissue (Tucker, 1987) and increased skeletal growth (Radcliff et al., 1997). Incorporation of additional dietary protein as RUP along with bST could be used to achieve early calving and maximal MY and sufficient body size to limit dystocia (Capuco et al., 2004). Contrary to earlier reports in which high energy intake (Sejrsen and Purup, 1997) was used to increase growth, and causes fat deposition, feeding pre-pubertal heifers RUP (7.9\% of DM) along with bST administration at $0.1 \mathrm{mg} / \mathrm{kg}$ BW per day, increased growth rates of skeletal tissues without increasing fat deposition (Moallem et al., 2004a; 2004b). However, daily administration of bST to Friesian heifers for $120 \mathrm{~d}$ before puberty did not affect BW gain, age at onset of puberty, reproductive efficiency, MY or milk composition during first lactation (Murphy et al., 1991). It appears that nutritional manipulations by feeding high RUP content along with hormone administration (i.e., bST) have no deleterious effect on mammary development in rapidly reared heifers because of increased skeletal growth rather than fat deposition.

\section{Effect of limit-feeding on heifer growth, mammary development and MY}

Limit-feeding is a management practice that controls feed intake to maximize nutrient utilization and to improve feed conversion ratio (Murphy and Loerch, 1994; Galyean, 1999). Lammers et al. (1999) used a limit-feeding strategy to control growth rates of prepubescent Holstein heifers and observed no negative carryover effects on first-lactation performance. Limit feeding more nutrient-dense diets 
compared with control diets for ad libitum intake to gravid dairy heifers may be an equally effective management strategy to control energy intake, compared to feeding high fibre forage diets (Hoffman et al., 2007). Improved feed efficiency and unaltered growth and first-lactation MY have been observed with dairy heifers fed before puberty a high concentrate diet compared with heifers fed a high forage diet for equal BW gains (Zanton and Heinrichs, 2007). Limit feeding improved feed efficiency and reduced DM excretion without negative effects on lactation performance. Dairy heifers were limit-fed $(1.25,1.50,1.75$, and $2.00 \%$ of $\mathrm{BW}$ ) a high forage diet; the efficiency of nutrient utilization increased as intake increases but reducing dry matter intake below $1.50 \%$ of BW reduced efficiency (Zanton and Heinrichs, 2008b). Restricting the amount of concentrate from $2 \mathrm{~kg} / \mathrm{d}$ per calf to $1 \mathrm{~kg} / \mathrm{d}$ from 5 to $7 \mathrm{~d}$ of age for the next $150 \mathrm{~d}$, moderately reduced the growth rates (BW gain, 827 vs $739 \mathrm{~g} / \mathrm{d}$ ) in German Holstein calves, and the effects were significant but final BW were not different (Lohakare et al., 2012). Calves in both groups received similar MR until weaning; however, group forage intake of restricted animals was higher than that of control calves.

Recent studies on primiparous Holsteins indicated that controlling or restricting energy intake pre-partum was not detrimental to lactation performance during the first 8 weeks of lactation (Janovick and Drackley, 2010). Ford and Park (2001) used a stair-step compensatory nutrition pattern to dairy heifers and reared according to an alternating 3-24-3-4-2-months schedule. The first stair-step (pre-pubertal phase) consisted of energy restriction (17\% $\mathrm{CP}$ and $9.8 \mathrm{MJ}$ $\mathrm{ME} / \mathrm{kg}$ ) for 3 months followed by realimentation (12\% CP and $12.8 \mathrm{MJ} \mathrm{ME} / \mathrm{kg}$ ) for 2 months. The second step (puberty and breeding) consisted of energy restriction for 4 months followed by realimentation for 3 months. The third step (gestation period) was energy restriction for 4 months concluding with realimentation for 2 months. Heifers were restricted to $70 \% \mathrm{DM}$ intake of the control intake during restriction phase and were given ad libitum access to high energy diets during realimentation. Heifers on stair-step regimen had a significant increase in MY during the first $(21 \%)$ and second $(15 \%)$ lactation cycles, had similar end BW while consuming less feed, thus improving efficiency of growth. Therefore, it appears that allowing compensatory growth may improve mammary development and energy and protein metabolic status of dairy heifers (Ford and Park, 2001). Similarly, nutritional restriction for $91 \mathrm{~d}$ followed by realimentation in beef heifers (226 d of age) was associated with increased parenchymal DNA concentrations, suggesting more cells in the mammary parenchymal tissue of these heifers compared with those on ad libitum intake (Yambayamba and Price, 1997). On similar lines, a well controlled nutritional regimen prior to first parturition can significantly affect mammary growth, differentiation, and performance at subsequent lactations (Park et al., 1987; Park et al., 1989; Choi et al., 1997; Park et al., 1998). Taken together, it appears that limit-feeding could be used as an alternative strategy for replacement dairy heifers.

\section{CONCLUSIONS}

Overall, feeding contributes significantly to growth; mammary development and MY potential from birth to calving; and ways of rearing the dairy heifer that optimizes first lactation MY and maintaining longevity should be continuously researched. Data suggest that diets for accelerated gains without negative effect on first-lactation MY or mammary growth can be developed. With the increase in growth rates due to genetic selection, CP requirements of heifers increase and so the $\mathrm{CP}$ to energy ratio should be higher for rapidly growing heifers. Effects of such high protein, high energy diets on dairy heifers in relation to changes in body composition and their role in mammary development and MY potential need further evaluation. Such studies will improve the knowledge for establishing future recommendations for dairy replacement heifers.

\section{ACKNOWLEDGEMENTS}

The authors deeply thank Alexander von HumboldtFoundation, Bonn, Germany, for providing financial support to the first author in the form of a Humboldt Research Fellowship during the stay at the University of Bonn.

Based in part on an invited paper presented at Korean Society of Animal Science and Technology Conference, held at Sunchon, Republic of Korea, 25-26 June 2009.

\section{REFERENCES}

Abeni, F., L. Calamari, L. Stefanini and G. Pirlo. 2000. Effects of daily gain in pre- and postpubertal replacement dairy heifers on body condition score, body size, metabolic profile, and future milk production. J. Dairy Sci. 83:1468-1478.

Akers, R. M. 2002. Lactation and the mammary gland. Blackwell Publishing, Ames, Iowa.

Akers, R. M., A. V. Capuco and J. E. Keys. 2006. Mammary histology and alveolar cell differentiation during late gestation and early lactation in mammary tissue of beef and dairy heifers. Livest. Sci. 105:44-49.

Arije, G. F. and J. N. Wiltbank. 1971. Age and weight at puberty in Hereford heifers. J. Anim. Sci. 33:401-406.

Bar-Peled, U., B. Robinzon, E. Maltz, H. Tagari, Y. Folman, I. Bruckental, H. Voet, H, Gacitua and A. R. Lehrer. 1997. Increased weight gain and effects on production parameters of Holstein heifer calves that were allowed to suckle from birth to 
6 weeks of age. J. Dairy Sci. 80:2523-2528.

Bleach, E., M. Gould, N. Blackie and D. Beever. 2005. Growth performance of Holstein-Friesian heifer calves reared using three milk replacer feeding regimes. In: Recent Advances in Animal Nutrition (Ed. P. C. Garnsworthy and J. Wiseman). Nottingham University Press, Nottingham. pp. 347-357.

Brown, E. G., M. J. VandeHaar, K. M. Daniels, J. S. Liesman, L. T. Chapin, J. W. Forrest, R. M. Akers, R. E. Pearson and M. S. Weber Nielsen. 2005a. Effect of increasing energy and protein intake on mammary development in heifer calves. J. Dairy Sci. 88:595-603.

Brown, E. G., M. J. VandeHaar, K. M. Daniels, J. S. Liesman, L. T. Chapin, D. H. Keisler and M. S. Weber Nielsen. 2005b. Effect of increasing energy and protein intake on body growth and carcass composition of heifer calves. J. Dairy Sci. 88:585-594.

Buskirk, D. D., D. B. Faulkner, W. L. Hurley, D. J. Kesler, F. A Ireland, T. G. Nash, J. C. Castree and J. L. Vicini. 1996. Growth, reproductive performance, mammary development, and milk production of beef heifers as influenced by prepubertal dietary energy and administration of bovine somatotropin. J. Anim. Sci. 74:2649-2662.

Buskirk, D. D., D. B. Faulkner and F. A. Ireland. 1995. Increased postweaning gain of beef heifers enhances fertility and milk production. J. Anim. Sci. 73:937-946.

Capuco, A. V., G. E. Dahl, D. L. Wood, U. Moallem and R. E. Erdman. 2004. Effect of bovine somatotropin and rumenundegradable protein on mammary growth of prepubertal dairy heifers and subsequent milk production. J. Dairy Sci. 87:37623769.

Capuco, A. V., S. E. Ellis, S. A. Hale, E. Long, R. A. Erdman, X. Zhao and M. J. Paape. 2003. Lactation persistency: Insights from mammary cell proliferation studies. J. Anim. Sci. 81:1831.

Capuco, A. V., J. J. Smith, D. R. Waldo and C. E. Rexroad. 1995. Influence of prepubertal dietary regimen on mammary growth of Holstein heifers. J. Dairy Sci. 78:2709-2725.

Carson, A. F., L. E. R. Dawson, A. R. G. Wylie and F. J. Gordon. 2004. The effect of rearing regime on the development of the mammary gland and claw abnormalities in high genetic merit Holstein-Friesian dairy herd replacements. Anim. Sci. 78:479509.

Carson, A. F., A. R. G. Wylie, J. D. G. Mc Evoy, M. A. McCoy and L. E. R. Dawson. 2000. The effects of plane of nutrition and diet type on metabolic hormone concentrations, growth and milk production in high genetic merit dairy herd replacements. Anim. Sci. 70:349-362.

Choi, Y. J., I. K. Han, J. H. Woo, H. J. Lee, K. Jang, K. H. Myung and Y. S. Kim. 1997. Compensatory growth in dairy heifers: the effect of a compensatory growth pattern on growth rate and lactation performance. J. Dairy Sci. 80:519-524.

Daniels, K. M., M. L. McGilliard, M. J. Meyer, M. E. Van Amburgh, A. V. Capuco and R. M. Akers. 2009. Effects of body weight and nutrition on histological mammary development in Holstein heifers. J. Dairy Sci. 92:499-505.

Davis Rincker, L. E., M. S. Weber Nielsen, L. T. Chapin, J. S. Liesman, K. M. Daniels, R. M. Akers and M. J. VandeHaar. 2008. Effects of feeding prepubertal heifers a high-energy diet for three, six, or twelve weeks on mammary growth and composition. J. Dairy Sci. 91:1926-1935.

Djonov, V., A. C. Andres and A. Ziemiecki. 2001. Vascular remodeling during the normal and malignant life cycle of the mammary gland. Microsc. Res. Tech. 52:182-189.

Dobos, R. C., K. S. Nandra, K. Riley, W. J. Fulkerson, I. J. Lean and R. C. Kellaway. 2000. The effect of dietary protein level during the pre-pubertal period of growth on mammary gland development and subsequent milk production in Friesian heifers. Livest. Prod. Sci. 63:235-243.

Drackley, J. K. 2005. Early growth effects on subsequent health and performance of dairy heifers. In: Calf and Heifer Rearing (Ed. P. C. Garnsworthy). Nottingham University Press, Nottingham. pp. 213-235.

Foldager, J. and C. C. Krohn. 1994. Heifer calves reared on very high or normal levels of whole milk from birth to six to eight weeks of age and their subsequent milk production. Proc. Soc. Nutr. Physiol. 3:301

Foldager, J. and K. Sejrsen. 1991. Rearing intensity in dairy heifers and the effect on subsequent milk production. National Institute of Animal Science, Foulum, Denmark, Report 693.

Ford, J. A. Jr. and C. S. Park. 2001. Nutritionally directed compensatory growth enhances heifer development and lactation potential. J. Dairy Sci. 84:1669-1678.

Galyean, M. L. 1999. Review: restricted and programmed feeding of beef cattle - definitions, application, and research results. Prof. Anim. Sci. 15:1-6.

Gardner, R. W., J. D. Schuh and L. G. Vargus. 1977. Accelerated growth and early breeding of Holstein heifers. J. Dairy Sci. 60:1941-1948.

Garnsworthy, P. C. and G. P. Jones. 1987. The influence of body condition at calving and dietary protein supply on voluntary food intake and performance in dairy cows. Anim. Prod. 44:347-353.

Gaynor, P. J., D. R. Waldo, A. V. Capuco, R. A. Erdman and L. W. Douglass. 1995. Effects of prepubertal growth rate and diet on lipid metabolism in lactating Holstein cows. J. Dairy Sci. 78:1534-1543.

Grummer, R. R., P. C. Hoffman, M. L. Luck and S. J. Bertics. 1995. Effect of prepartum and postpartum dietary energy on growth and lactation of primiparous cows. J. Dairy Sci. 78:172-180.

Harrison, R. D., I. P. Reynolds and W. Little. 1983. A quantitative analysis of mammary glands of dairy heifers reared at different rates of live weight gain. J. Dairy Res. 50:405-412.

Heinrichs, A. J. 1993. Raising dairy replacements to meet the needs of the 21 st century. J. Dairy Sci. 76:3179-3187.

Hill, T. M., H. G. Bateman, J. M. Aldrich and R. L. Schlotterbeck. 2010. Effect of milk replacer program on digestion of nutrients in dairy calves. J. Dairy Sci. 93:1105-1115.

Hoffman, P. C. 1997. Optimum body size of Holstein replacement heifers. J. Anim. Sci. 75:836-845.

Hoffman, P. C., N. M. Brehm, S. G. Price and A. Prill-Adams. 1996. Effect of accelerated postpubertal growth and early calving on lactation performance of primiparous Holstein heifers. J. Dairy Sci. 79:2024-2031.

Hoffman, P. C., N. M. Esser, L. M. Bauman, S. L. Denzine, M. Engstrom and H. Chester-Jones. 2001. Short communication: Effect of dietary protein on growth and nitrogen balance of 
Holstein heifers. J. Dairy Sci. 84:843-847.

Hoffman, P. C. and D. A. Funk. 1992. Applied dynamics of dairy replacement growth and management. J. Dairy Sci. 75:25042516.

Hoffman, P. C., C. R. Simson and M. Wattiaux, M. 2007. Limit feeding of gravid Holstein heifers: effect on growth, manure nutrient excretion, and subsequent early lactation performance. J. Dairy Sci. 90:946-954.

Hohenboken, W. D., J. Foldager, J. Jensen, P. Madsen and B. B. Andersen. 1995. Breed and nutritional effects and interactions on energy intake, production and efficiency of nutrient utilization in young bull, heifers and lactating cows. Acta Agric. Scand. Sect. A. Anim. Sci. 45:92-98.

Holmes, C. W., I. M. Brookers, D. J. Garrick, D. D. S. Mackenzie, T. J. Parkinson and G. F. Wilson. 2002. Milk Production from Pasture. Massey University, Palmerston North.

Janovick, N. A. and J. K. Drackley. 2010. Prepartum dietary management of energy intake affects postpartum intake and lactation performance by primiparous and multiparous Holstein cows. J. Dairy Sci. 93:3086-3102.

Jasper, J. and D. M. Weary. 2002. Effects of ad libitum milk intake on dairy caves. J. Dairy Sci. 85:3054-3058.

Johnsson, I. D. 1988. The effect of pubertal nutrition on lactation performance by dairy cows. In: Nutrition and Lactation in the Dairy Cow (Ed. P. C. Garnsworthy). Butterworths, London, pp. 171-192.

Kearl, L. C. 1982. Nutrient requirement of ruminants in developing countries. International feedstuffs Institute, Utah Agricultural Experiment Station, Utah State University, Logan, UT.

Khan, M. A., H. J. Lee, W. S. Lee, H. S. Kim, K. S. Ki, T. Y. Hur, G. H. Suh, S. J. Kang and Y. J. Choi. 2007. Structural growth, rumen development, and metabolic and immune responses of Holstein male calves fed milk through step-down and conventional methods. J. Dairy Sci. 90:3376-3387.

Knight, C. H. 2000. The importance of cell division in udder development and lactation. Livest. Prod. Sci. 66:169-176.

Lacasse, P., E. Block, L. A. Guilbault and D. Petitclerc. 1993. Effect of plane of nutrition of dairy heifers before and during gestation on milk production, reproduction and health. J. Dairy Sci. 76:3420-3427.

Lammers, B. P., A. J. Heinrichs and R. S. Kensinger. 1999. The effects of accelerated growth rates and estrogen implants in prepubertal Holstein heifers on estimates of mammary development and subsequent reproduction and milk production. J. Dairy Sci. 82:1753-1764.

Le Cozler, Y., V. Lollivier, P. Laccase and C. Disenhaus. 2008. Rearing strategy and optimising first-calving targets in dairy heifers: a review. Animal 2:1393-1404.

Lohakare, J. D., A. K. Pattanaik and S. A. Khan. 2006. Effect of dietary protein levels on the performance, nutrient balances, metabolic profile, and thyroid hormones of crossbred calves. Asian-Aust. J. Anim. Sci. 19:1588-1593.

Lohakare, J. D., H. van de Sand, K. Gerlach, A. Hosseini, M. Mielenz, H. Sauerwein, M. Pries and K. -H. Südekum. 2012. Effects of limited concentrate feeding on growth and blood and serum variables, and on nutrient digestibility and gene expression of hepatic gluconeogenic enzymes in dairy calves. J.
Anim. Physiol. Anim. Nutr. 96:25-36.

Macdonald, K. A., J. W. Penno, A. M. Bryant and J. R. Roche. 2005. Effect of feeding level pre- and post-puberty and body weight at first calving on growth, milk production, and fertility in grazing dairy cows. J. Dairy Sci. 88:3363-3375.

Macdonald, K. A., L. R. McNaughton, G. A. Verkerk, J. W. Penno, L. J. Burton, D. P. Berry, P. J. S. Gore, J. A. S. Lancaster and C. W. Holmes. 2007. A comparison of three strains of HolsteinFriesian cows grazed on pasture: growth, development and puberty. J. Dairy Sci. 90:3993-4003.

Mäntysaari, P., K. L. Ingvartsen and V. Toivonen. 1999. Feeding intensity of pregnant heifers: effect of feeding intensity during gestation on performance and plasma parameters of primiparous Ayrshire cows. Livest. Prod. Sci. 62:29-41.

Meyer, M. J., A. V. Capuco, D. A. Ross, L. M. Lintault and M. E. Van Amburgh. 2006a. Developmental and nutritional regulation of the prepubertal heifer mammary gland: I. Parenchyma and fat pad mass and composition. J. Dairy Sci. 89:4289-4297.

Meyer, M. J., A. V. Capuco, D. A. Ross, L. M. Lintault and M. E. Van Amburgh. 2006b. Developmental and nutritional regulation of the prepubertal bovine mammary gland: II. Epithelial cell proliferation, parenchymal accretion rate, and allometric growth. J. Dairy Sci. 89:4298-4304.

Moallem, U., G. E. Dahl, E. K. Duffey, A. V. Capuco and R. A. Erdman. 2004a. Bovine somatotropin and rumen-undegradable protein effects on skeletal growth in prepubertal dairy heifers. J. Dairy Sci. 87:3881-3888.

Moallem, U., G. E. Dahl, E. K. Duffey, A. V. Capuco, D. L. Wood, K. R. McLeod, R. L. Baldwin VI and R. A. Erdman. 2004b. Bovine somatotropin and rumen-undegradable protein effects in prepubertal dairy heifers: effects on body composition and organ and tissue weights. J. Dairy Sci. 87:3869-3880.

Moallem, U., D. Werner, H. Lehrer, M. Zachut, L. Livshitz, S. Yakoby and A. Shamay. 2010. Long-term effects of ad libitum whole milk prior to weaning and prepubertal protein supplementation on skeletal growth rate and first-lactation milk production. J. Dairy Sci. 93:2639-2650.

Moore, R. K., B. W. Kennedy, L. R. Schaeffer and J. E. Moxley. 1991. Relationships between age and body weight at calving and production in first lactation Ayrshires and Holsteins. J. Dairy Sci. 74:269-278.

Murphy, M. G., M. Rath, D. O'Callaghan, F. H. Austin and J. F. Roche. 1991. Effect of bovine somatotropin on production and reproduction in prepubertal Friesian heifers. J. Dairy Sci. 74:2165-2171.

Murphy, T. A. and S. C. Loerch. 1994. Effects of restricted feeding of growing steers on performance, carcass characteristics, and composition. J. Anim. Sci. 72:2497-2507.

NRC. 1989. Nutrient requirements of dairy cattle (6th Ed.). National Academy Press, Washington, DC, USA.

NRC. 2001. Nutrient requirements of dairy cattle (7th Ed.). National Academy Press, Washington, DC, USA.

Oltenacu, P. A. and D. M. Broom. 2010. The impact of genetic selection for increased milk yield on the welfare of dairy cows. Anim. Welf. 19(S):39-49.

Park, C. S., M. G. Baik, W. L. Keller, I. E. Berg and G. M. Erickson. 1989. Role of compensatory growth in lactation: 
stair-step nutrient regimen modulates differentiation and lactation of bovine mammary gland. Growth Dev. Aging 53:159-166.

Park, C. S., R. B. Danielson, B. S. Kreft, S. H. Kim, Y. S. Moon and W. L. Keller. 1998. Nutritionally directed compensatory growth and effects on lactation potential of developing heifers. J. Dairy Sci. 81:243-249.

Park, C. S., G. M. Erickson, Y. J. Choi and G. D. Marx. 1987. Effect of compensatory growth on regulation of growth and lactation. Response of dairy heifers to a stair-step growth pattern. J. Anim. Sci. 64:1751-1758.

Peri, I., A. Gestler, I. Bruckental and H. Barsh. 1993. The effect of manipulation in energy allowance during the rearing period of heifers on hormone concentrations and milk production in first lactation cows. J. Dairy Sci. 76:742-751.

Petitclerc, D., L. T. Chapin and H. A. Tucker. 1984. Carcass composition and mammary development responses to photoperiod and plane of nutrition in Holstein heifers. J. Anim. Sci. 58:913-919.

Pirlo, G., M. Capelletti and G. Marchetto. 1997. Effects of energy and protein allowances in the diets of prepubertal heifers on growth and milk production. J. Dairy Sci. 80:730-739.

Purup, S., K. Sejrsen, J. Foldager and R. M. Akers. 1993. Effect of exogenous bovine growth hormone and ovariectomy on prepubertal mammary growth, serum hormones, and in vitro proliferative response of mammary explants from Holstein heifers. J. Endocrinol. 139:19-26.

Radcliff, R. P., M. J. Vandehaar, L. T. Chapin, T. E. Pilbeam, D. K. Beede, E. P. Stanisiewski and H. A. Tucker. 2000. Effects of diet and injection of bovine somatotropin on prepubertal growth and first-lactation milk yields of Holstein cows. J. Dairy Sci. 83:23-29.

Radcliff, R. P., M. J. Vandehaar, A. L. Skidmore, L. T. Chapin, B. R. Radke, J. W. Llyod, E. P. Stanisiewski and H. A. Tucker. 1997. Effects of diet and bovine somatotropin on heifer growth and mammary development. J. Dairy Sci. 80:1996-2003.

Raeth-Knight, M., H. Chester-Jones, S. Hayes, J. Linn, R. Larson, D. Ziegler, B. Ziegler and N. Broadwater. 2009. Impact of conventional or intensive milk replacer programs on Holstein heifer performance through six months of age and during first lactation. J. Dairy Sci. 92:799-809.

Safayi, S., P. K. Theil, V. S. Elbrond, L. Hou, M. Engbaek, J. V. Norgaard, K. Sejrsen and M. O. Nielsen. 2010. Mammary remodeling in primiparous and multiparous dairy goats during lactation. J. Dairy Sci. 93:1478-1490.

Sejrsen, K. 1994. Relationships between nutrition, puberty and mammary development in cattle. Proc. Nutr. Soc. 53:103-111.

Sejrsen, K. and J. Foldager. 1992. Mammary growth and milkproduction capacity of replacement heifers in relation to diet energy concentration and plasma-hormone levels. Acta Agric. Scand. Sec. A-Anim. Sci. 42:99-105.

Sejrsen, K., J. T. Huber, H. A. Tucker and R. M. Akers. 1982. Influence of nutrition on mammary development in pre- and postpubertal heifers. J. Dairy Sci. 65:793-800.

Sejrsen, K. and S. Purup. 1997. Influence of prepubertal feeding level on milk yield potential of dairy heifers: a review. J. Anim. Sci. 75:828-835.

Sejrsen, K., S. Purup, M. Vestergaard and J. Foldager. 2000. High body weight gain and reduced bovine mammary growth: physiological basis and implications for milk yield potential. Domest. Anim. Endocrinol. 19:93-104.

Shamay, A., D. Werner, U. Moallem, H. Barash and I. Bruckental. 2005. Effect of nursing management and skeletal size at weaning on puberty, skeletal growth rate, and milk production during first lactation of dairy heifers. J. Dairy Sci. 88:14601469.

Silva, L. F., M. J. VandeHaar, B. K. Whitlock, R. P. Radcliff and H. A. Tucker. 2002. Short communication: Relationship between body growth and mammary development in dairy heifers. J. Dairy Sci. 85:2600-2602.

Sinha, Y. N. and H. A. Tucker. 1969. Mammary development and pituitary prolactin level of heifer from birth through puberty and during the estrous cycle. J. Dairy Sci. 52:507-512.

Swanson, E. W. 1960. Effect of rapid growth with fattening of dairy heifers on their lactational ability. J. Dairy Sci. 43:377387.

Swanson, E. W. and J. I. Poffenbarger. 1979. Mammary gland development of dairy heifers during their first gestation. J. Dairy Sci. 62:702-714.

Tucker, H. A. 1987. Quantitative estimates of mammary growth during various physiological states: A review. J. Dairy Sci. 70:1958-1966.

Valentine, S. C., R. C. Dobos, P. A. Lewis, B. D. Bartsch and R. B. Wickes. 1987. Effect of live weight gain before or during pregnancy on mammary gland development and subsequent milk production of Australian Holstein-Friesian heifers. Aust. J. Exp. Agric. 27:195-205.

Van Amburgh, M. E., D. M. Galton, D. E. Bauman, R. W. Everett, D. G. Fox, L. E. Chase and H. N. Erb. 1998. Effects of three prepubertal body growth rates on performance of Holstein heifers during first lactation. J. Dairy Sci. 81:527-538.

Waldo, D. R., A. V. Capuco and C. E. Rexroad Jr. 1998. Milk production of Holstein heifers fed either alfalfa or silage diets at two rates of daily gain. J. Dairy Sci. 81:756-764.

Waldo, D. R., H. F. Tyrrell, A. V. Capuco and C. E. Jr. Rexroad. 1997. Components of growth in Holstein heifers fed either alfalfa or corn silage diets to produce two daily gains. J. Dairy Sci. 80:1674-1684.

Wathes, D. C., Z. Cheng, N. Bourne, V. J. Taylor, M. P. Coffey and S. Brotherstone. 2007. Differences between primiparous and multiparous dairy cows in the inter-relationships between metabolic traits, milk yield and body condition score in the periparturient period. Domest. Anim. Endocrinol. 33:203-225.

Whitlock, B. K., M. J. VandeHaar, L. F. P. Silva and H. A. Tucker. 2002. Effect of dietary protein on prepubertal mammary development in rapidly growing dairy heifers. J. Dairy Sci. 85:1516-1525.

Wiltbank, J. N., K. E. Gregory, L. A. Swiger, J. E. Ingalls, J. A. Rothlisberger and R. M. Koch. 1966. Effects of heterosis on age and weight at puberty in beef heifers. J. Anim. Sci. 25:744751.

Yambayamba, E. S. K. and M. A. Price. 1997. Effect of compensatory growth on mammary growth and development in beef heifers. Livest. Prod. Sci. 51:237-244.

Zanton, G. I. and A. J. Heinrichs. 2005. Meta-analysis to assess effect of prepubertal average daily gain of Holsteins heifers on 
first-lactation production. J. Dairy Sci. 88:3860-3867.

Zanton, G. I. and A. J. Heinrichs. 2007. The effects of controlled feeding of a high-forage or high-concentrate ration on heifer growth and first-lactation milk production. J. Dairy Sci. 90:3388-3396.
Zanton, G. I. and A. J. Heinrichs. 2008a. Analysis of nitrogen utilization and excretion in growing dairy cattle. J. Dairy Sci. 91:1519-1533.

Zanton, G. I. and A. J. Heinrichs. 2008b. Rumen digestion and nutritional efficiency of dairy heifers limit-fed high forage ration to four levels of dry matter intake. J. Dairy Sci. 91:35793588 . 